\title{
Effect of Chemical Treatment on Protein Profiling against Pre-Harvest Sprouting in Mung Bean
}

\author{
Priyanka Singh $^{1 *}$, V.K. Chourasiya ${ }^{2}$ and R.D.S. Yadav ${ }^{1}$ \\ ${ }^{1}$ Department of Seed Science and Technology, N.D.U.A.T Kumarganj, Faizabad \\ (U.P) 224229, India \\ ${ }^{2}$ G.B.P.U.A.T Pantnagar (U.K) 263145, India \\ *Corresponding author
}

\section{A B S T R A C T}

\begin{tabular}{|c|c|}
\hline $\begin{array}{l}\text { Chemical, Protein, } \\
\text { Pre-harvest } \\
\text { sprouting }\end{array}$ & $\begin{array}{l}\text { In the present study, SDS-Polyacrylamide gel electrophoresis was used to separate protein } \\
\text { sub units of albumin and globulin under reducing conditions to study the induction or } \\
\text { disappearance during inhibition of germination. The molecular masses of the albumin and } \\
\text { globulin protein subunits were estimated in relation to the motilities of the standard } \\
\text { molecular mass proteins (Bio-Rad). However the SDS PAGE resolution of seed albumin in }\end{array}$ \\
\hline Artic & \\
\hline $\begin{array}{l}\text { Accepted: } \\
07 \text { April } 2018 \\
\text { Available Online: } \\
10 \text { May } 2018\end{array}$ & $\begin{array}{l}42 \mathrm{kDa} \text { was observed in control. All treatment exhibited more no of high molecular weight } \\
\text { of protein band ranging } 9.14-83.30 \mathrm{kDa} \text {. The susceptibility was characterized by the } \\
\text { presence of high water soluble albumin fraction and relatively low globulin content in } \\
\text { samrat. }\end{array}$ \\
\hline
\end{tabular}

\section{Introduction}

Vigna radiata L. (Mungbean) commonly known as green gram is one of the important legume native to India (Bott and Kingston, 1976), highly rich in proteins, vitamin and minerals. It has high concentration of thymine, niacin and ascorbic acid. It requires low input and has wider adaptability to grow in short duration (90-120 days). They acquire 80 million hectares of land worldwide. Preharvest sprouting (PHS) is one of the most important factors to affect the yield and quality of crops worldwide especially in wet harvest period Bhuyan and Sharma (2006). The PHS is determined by environmental conditions, inner factors and interaction between these factors (Derera, 1989 Calero et al., 1981). Mungbean requires hot and dry climate. Cloudy weather, continuous and heavy rains adversely affect the flowering and poding in mungbean, causing low yields. Mungbean can be grown on well-drained loamy sand to sandy loam soils. The crop is sensitive to alkaline, saline or waterlogged soil. Being a short duration crop, mungbean is cultivated in all three seasons (kharif, rabi and zaid) in different parts of country as a pure crop as well as an associate crop in various cropping systems. Among the three seasons, kharif and zaid is most important and in this season pre-harvest sprouting is a big problem 
causing huge losses in production. Nearly 60$70 \%$ of yield losses have been reported in green gram and black gram due to pre-harvest sprouting (Durga et al., 1997; Davidson, 1985). The pre-harvest sprouting is sometimes referred to as weather damage. Weather damage is a general term used to describe a range of adverse physical and chemical changes that occur in seed following its exposure to rainfall and humidity. In view of the substantial losses caused by pre-harvest sprouting, it is imperative to develop preharvest sprouting tolerant varieties are need to identify sources of short duration with certain period of dormancy to minimize yield losses due to in situ germination (Ashok Kumar, 1989 and Patil et al., 1991; Imrie, 1983). However, the information on pre-harvest sprouting is lacking because little work has been done on this aspect of the crop.

Dormancy is an important factor in commercial groundnut production. It can be beneficial when dormancy prevents mature seeds from sprouting before harvest. It can be detrimental when dormancy reduces stand or hampers taking a second crop immediately after harvest. Lack of dormancy in mung bean has been described as an inherent property of seed and does not primarily depend on soil conditions.

Seed exhibit primary dormancy during development and developing seed rarely germinate. But precocious germination is reported to be associated with deficiencies in ABA synthesis / (Black, 1991; Hilhorst, 1995 and Karssen, 1995). Hence prevention of germination during development may be due to the endogenous ABA content of the seed or naturally widespread occurance of coumarin and derivatives or the osmotic environment surrounding the seed or both (Berry and Bewley, 1992; Mayer, 1989; Chen et al., 2007; Gubler et al., 2005). Absence or insensitivity to ABA during seed development results in the production of viviparous or precociously germinating seeds as it is evident from the deficient ABA-mutant responsiveness (Le Page-Degivry and Garelio 1992). Protein synthesis/degradation appear to be obligatory for seed germination in most cases, if not all species (Bewely and Marcus, 1990).

Some specific $23 \mathrm{kDa}$ proteins were found strongly increased upon release of dormancy. Dormant embryo of oat, showed $44 \mathrm{kDa}$ and $2 \mathrm{kDa}$ proteins, compared to $26 \mathrm{kDa}$ protein bands in the extracts of non-dormant embryo (Corbineau et al., 1991).

The search for investigation of nonconventional methods of inducing dormancy in mung bean to save the produce and to retain the seed quality against the field sprouting are of greater importance. For inducing seed dormancy in Mung bean number of methods have been developed (Appalanaida and Murthy, 1961) Foliar application of maleic hydrazide (Berrie et al., 1968) and coumarin different stages of crop growth has been successfully used to control sprouting.

The key idea in the use of growth regulators is to control some aspects of growth, regulate the balance between source and sink, which is the final analysis results in the higher yield of desired product. We here reviewed recent advances influencing factors of PHS, including seed dormancy, seed coat permeability and color, á-amylase activities, endogenous hormones levels, genes and different protein profiling in different genotypes (Lakhanpaul and Bhat, 2000).

Breeding PHS-resistant cultivars has important implications to improve the mung quality and production (Dickson, 1980). Banding pattern analysis showed polymorphism for the presence of different bands with different molecular weight of total 
seed proteins in mungbean cultivars were subjected to SDS-polycrylamide gel electrophoresis (Naik and Kole, 2001).

\section{Materials and Methods}

The experiment was conducted during zaid 2014-15 at student instructional farm of N.D.U.A.T University of Agriculture and Technology, Kumarganj. The experimental materials for the study consisted of four mungbean genotypes comprising of released varieties, advance breeding lines of inter varietal and inter specific origin, local germplasm, collections, the wild progenitor of mung bean (Vigna radiate var: sublobata). The field experiment was laid out Factorial Randomizied Block Design. Each genotypes was planted in two rows of $4 \mathrm{~m}$ with spacing $60 \times 10 \mathrm{~cm}$. The laboratory evaluation was conducted in Completely Randomized Design (CRD) with 3 replications for each genotype.

Testing the protein banding through electrophoresis test (SDS PAGE).

During the present studies, SDS poly acryl amide gel electrophoresis was used to separate the protein sub unit of albumin and globulin under reducing condition to study the induction or disappearance of existed subunit during inhibition of germination. The molecular masses of the albumin and globulin protein subunits were estimated in the relation to the motilities of the standard molecular mass protein.

\section{Preparation of reagent}

$30 \%$ acryl amide: dissolved $29.8 \mathrm{~g}$ acryl amide and $0.8 \mathrm{~g}$ of bis acrylamide in $100 \mathrm{ml}$ of water.

1.5M of tris HCL buffer $\mathrm{pH}$ 8.8: Dissolves $9 \mathrm{~g}$ of tris (hydroxyl methyl) amino methane in 50 $\mathrm{ml}$ of water and adjusted $\mathrm{pH}$ to 8.8 with $1 \mathrm{~N}$ $\mathrm{HCl}$.
1.0M tris $\mathrm{HCl}$ buffer, $\mathrm{pH}, 6.8$ : Dissolved $6 \mathrm{~g}$ of tris (hydroxyl methyl) amino methane in 50 $\mathrm{ml}$ of water and adjusted $\mathrm{pH}$ to 6.8 with $1 \mathrm{~N}$ $\mathrm{HCl}$.

$10 \%$ of SDS: Dissolved 100mg of sodium dodecyl sulfate in $1 \mathrm{ml}$ of water.

10\% APS: Dissolved 100mg of Ammonium persulfate in $1 \mathrm{ml}$ of water.

TEMED (N, N, N', N Tetramethylethylene diamine.

2\% Agar: Dissolved $2 \mathrm{~g}$ of agar in $50 \mathrm{ml}$ of water.

Sample buffer: Mixed $1 \mathrm{ml}$ of $1 \mathrm{M}$ of tris $\mathrm{HCl}$, $\mathrm{pH}, 6.8,1 \mathrm{ml}$ of beta marcaptoethanol, $4 \mathrm{ml}$ of $10 \%$ SDS, $20 \mathrm{mg}$ of bromophenol blue and $2 \mathrm{ml}$ of glycerol, finally made up to $20 \mathrm{ml}$ with distilled water.

Electrode buffer /Running buffer: (tris glycene buffer, $\mathrm{pH}, 8.3$ ): Prepared 5x of dissolving $15.1 \mathrm{~g}$ of tris, $94 \mathrm{~g}$ of glycine, $50 \mathrm{ml}$ of $10 \%$ SDS in about $80 \mathrm{ml}$ of water and finally made up to 1 liter. This was diluted one in five times and used.

\section{Gel preparation}

Separating and staking gels were prepared as follow by mixing the following content:

Sample preparation: Albumin and globulin protein samples were diluted in sample buffer to get final concentration of $350-400 \mathrm{ug} / \mathrm{ml}$. These samples were boiled for $3-5 \mathrm{~min}$ in a boiling water bath and centrifuged at $1000 \mathrm{rpm} / 3 \mathrm{~min}$ before loading the sample.

Staining solution:

Coomassie brilliant blue (0.1\%): $0.1 \mathrm{~g}$

Methanol: $50 \mathrm{ml}$ 
Glacial acetic acid: $10 \mathrm{ml}$

De ionized water: $40 \mathrm{ml}$

Destaining solution:

Acetic aci: $10 \mathrm{ml}$

Methanol: $50 \mathrm{ml}$

De ionized water: $40 \mathrm{ml}$

\section{Procedure}

SDS PAGE was carried separately for albumin and globulin on a vertical mini slab gel electrophoresis (BIO RAD) with a gel of $1 \mathrm{~mm}$ thickness as per the procedure described by Laemmli (1970).

Slab gel formed in a glass stand made of two flat glass plates separated by two spacer $=06$ strips at the edges clamped together to make a water tight seal. The two glass plates are mounted vertically into a cast containing boiled agar for sealing the bottom. After the agar was cooled, the $12 \%$ separated gel is loaded into vertical slab between two glass plates and allowed to polymerize for $30 \mathrm{~min}$. The gel was loaded just below the level of the comb to be placed. n Butanol is sprayed over the separating gel for even surface of the gel and also prevent drying of the gel. n-Butanol removed with filter paper after gel polymerized.5\% stacking is sprayed over the separating gel. Sample wells are made at one end of the gel by placing the comb shaped jig into stacking gel before it sets of polymerized. The stacking gel was allowed to polymerized for about $30 \mathrm{~min}$ so that the wells can be cast side by side.

After gel was properly set, the comb was removed carefully and running buffer was poured into lower and upper buffer reservoirs. Sample (30ul each variety) were carefully loaded into the hives of the comb using the micro syringe. The two terminal anode and cathode are connected with anode to lower reservoir and cathode to upper reservoir. The instrument was switch on with current of 25mAmps. After the dye displaces to separating gel current was increased to $30 \mathrm{mAmps}$. Electrophoresis was carried for 2 or 3 hrs until the dye moves the gel till the agar marl. The gel was removed and immersed in a fixative (7\% acetic acid) to gourd against diffusion of separated component.

\section{Staining and destaining}

Gel was stained in coomassie brilliant blue staining solution for $1 \mathrm{hrs}$. Excess stain was removed by washing the gel in the Destaining solution.

\section{Statistical analysis}

The data with respect to various characters for 14 mungbean genotypes was subjected to the following statistical and genetically analysis in the present investigation.

Analysis of variance

Correlation coefficient

Various observations recorded as above were pooled trait wise and statically

The data obtained pertain to lab experiment (invitro) from the present were processed and analysed statistically using CRD design by Fisher and Yates (1963).

\section{Results and Discussion}

Protein profile of albumin and globulin fraction in four genotype of mung bean against pre harvest sprouting susceptible and tolerance genotype.

After quantitative and qualitative estimation of albumin (water soluble) and globulin (salt soluble) of mungbean genotypes were further subjected to SDS-PAGE resolution as shown 
in plate 10-17. The protein profile of albumin and globulin in mungbean genotypes viz., Pusa vishal, K851, HUM16 and Samrat are given in this paragraph.

\section{Albumin}

\section{HUM16}

The SDS-PAGE analysis of the cv.HUM16 displayed protein bands of molecular weight ranging from 6.3-137 $\mathrm{kDa}$. A minimum number of bands (5) were developed by Mallic hydrazide treated seed whereas ABA could do a maximum number of bands (3). The polypeptides of high intensity corresponding to the molecular weights of $34 \mathrm{kDa}-26 \mathrm{kDa}$ were found commonly developed by all the treatments. A single band of low intensity but heavy molecular weight $(136 \mathrm{kDa})$ was developed under simulated with water. The band pattern of the treatments suggests both qualitative and quantitative differences shown in plate 1 .

\section{Samrat}

SDS-PAGE analysis of mungbean cv. Samrat showed average number of protein bands ranged from 5-12 corresponding to molecular weight from 20-110kDa. Coumarin could develop maximum number of bands (10) while $\mathrm{GA}_{3}$ showed minimum bands (plate 2).

A polypeptide of high intense with a molecular weight $31 \mathrm{kDa}$ and $25 \mathrm{kDa}$ were found in all the treatments. The band with heavy molecular weight $111.1 \mathrm{kDa}$ was developed only in coumarin and maleic hydrazide treatment. Two polypeptides of low molecular weight of 7.6 and $5.9 \mathrm{kDa}$ were seen with but not in other treatments. Similarly a band of $33 \mathrm{kDa}$ was developed under simulation only but not found in other treatments, while a polypeptide of $42 \mathrm{kDa}$ was common to both coumarin and control.

\section{Pusa vishal}

SDS-PAGE resolution of albumin protein fraction in seeds of mungbean cv., Pusa vishal as influenced by different treatments under simulated rain is shown in plate 3. Total number of protein bands in untreated control seed was 11 with a molecular weight ranging from 8.7-64.0 $\mathrm{kDa}$. Where as in simulated rain, thirteen bands with molecular weight ranged from 9.80 to $82.4 \mathrm{kDa}$. All treatments exhibited more number of high molecular weight of bands ranging from 9.10-83.20. However, in case of coumarin treated seed, the bands were only ten, while treatments Mallic hydrazide and $\mathrm{ABA}$ at par without simulation of rain.

\section{K851}

SDS-PAGE resolution of seed albumin profile of mungbean cv.K851 as affected by different treatment under simulated rain as is shown in plate 2. The number of protein bands as influenced by the treatments ranged from 8-12 with molecular weights from 110-5.27 kDa present in coumarin and Mallic hydrazide treated sample. A minimum number of bands but of high intensity were observed only in ABA treated seeds. A new protein with low molecular weight band appeared at $15.95 \mathrm{kDa}$ in coumarin treated seed which was not found in other treatments. It clearly indicated that a new protein is synthesized the coumarin treated seeds.

Protein bands of molecular weight 31, 25 and $27 \mathrm{kDa}$ were found common to all the treatments. A light intensive band of molecular weight $40 \mathrm{kDa}$ was observed only in simulated with water. Thus this result revealed that the water -soluble protein of high medium and low molecular weight have been synthesized and exhibited greater heterogenetly due to different impact of treatments and genotypes under simulated condition. Shown plate 4. 


\section{Gel preparation}

\begin{tabular}{lcc}
\hline Content & $\begin{array}{c}\text { for separating gel 12\% } \\
\text { (Total volume of 10ml) }\end{array}$ & $\begin{array}{c}\text { for staking gel 3\% } \\
\text { (Total volume of 3ml) }\end{array}$ \\
\hline $30 \%$ acrylamide & $4.0 \mathrm{ml}$ & $0.5 \mathrm{ml}$ \\
1.5 tris HCL pH 8.8 & $3.3 \mathrm{ml}$ & - \\
1.0 tris HCL pH 6.8 & - & $0.38 \mathrm{ml}$ \\
Distilled water & $3.3 \mathrm{ml}$ & $2.1 \mathrm{ml}$ \\
$10 \%$ SDS & $0.1 \mathrm{ml}$ & $0.3 \mathrm{ml}$ \\
$10 \%$ APS & $0.1 \mathrm{ml}$ & $0.3 \mathrm{ml}$ \\
TEMED & $0.004 \mathrm{ml}$ & $0.003 \mathrm{ml}$
\end{tabular}
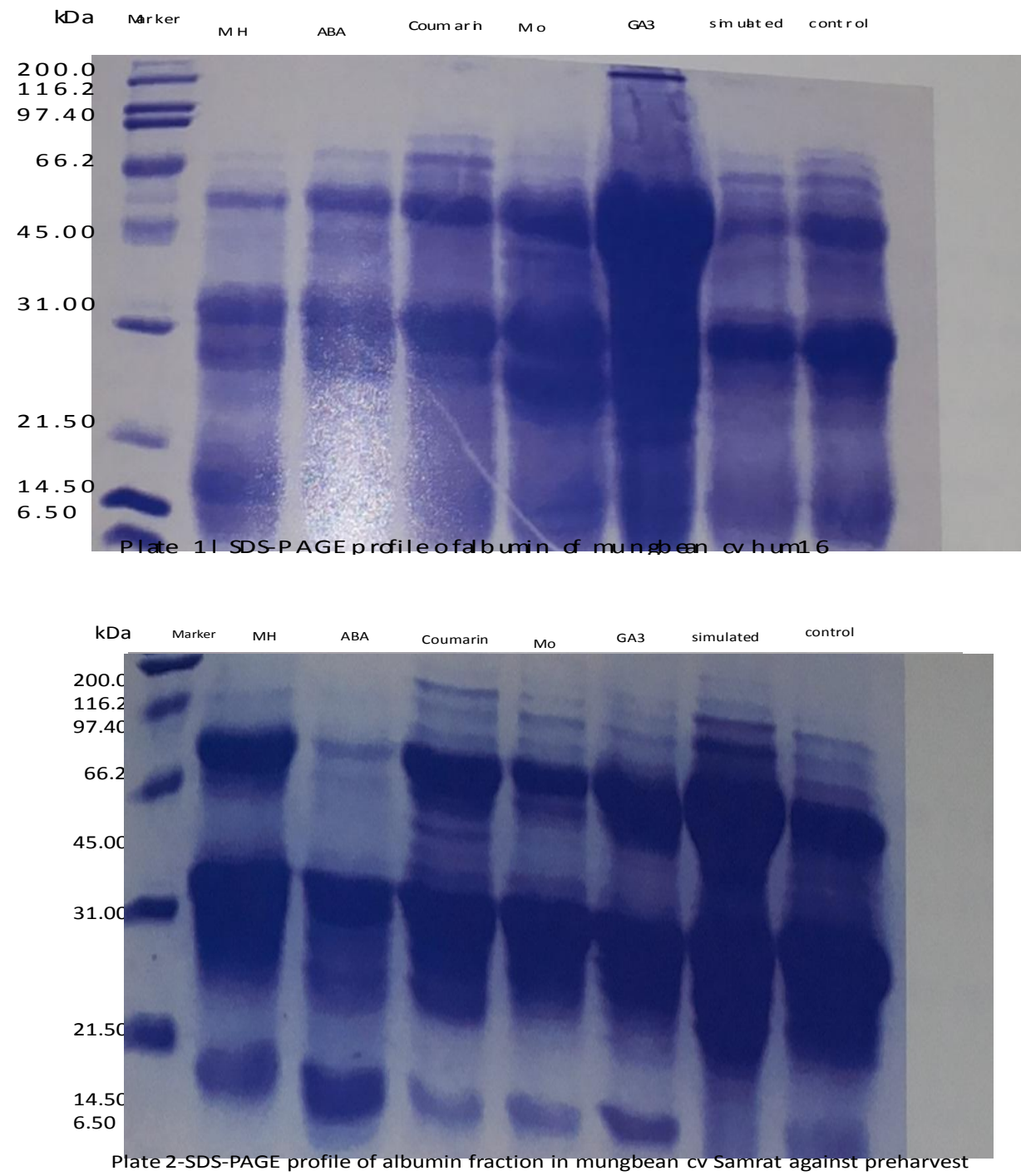
Int.J.Curr.Microbiol.App.Sci (2018) 7(5): 539-550
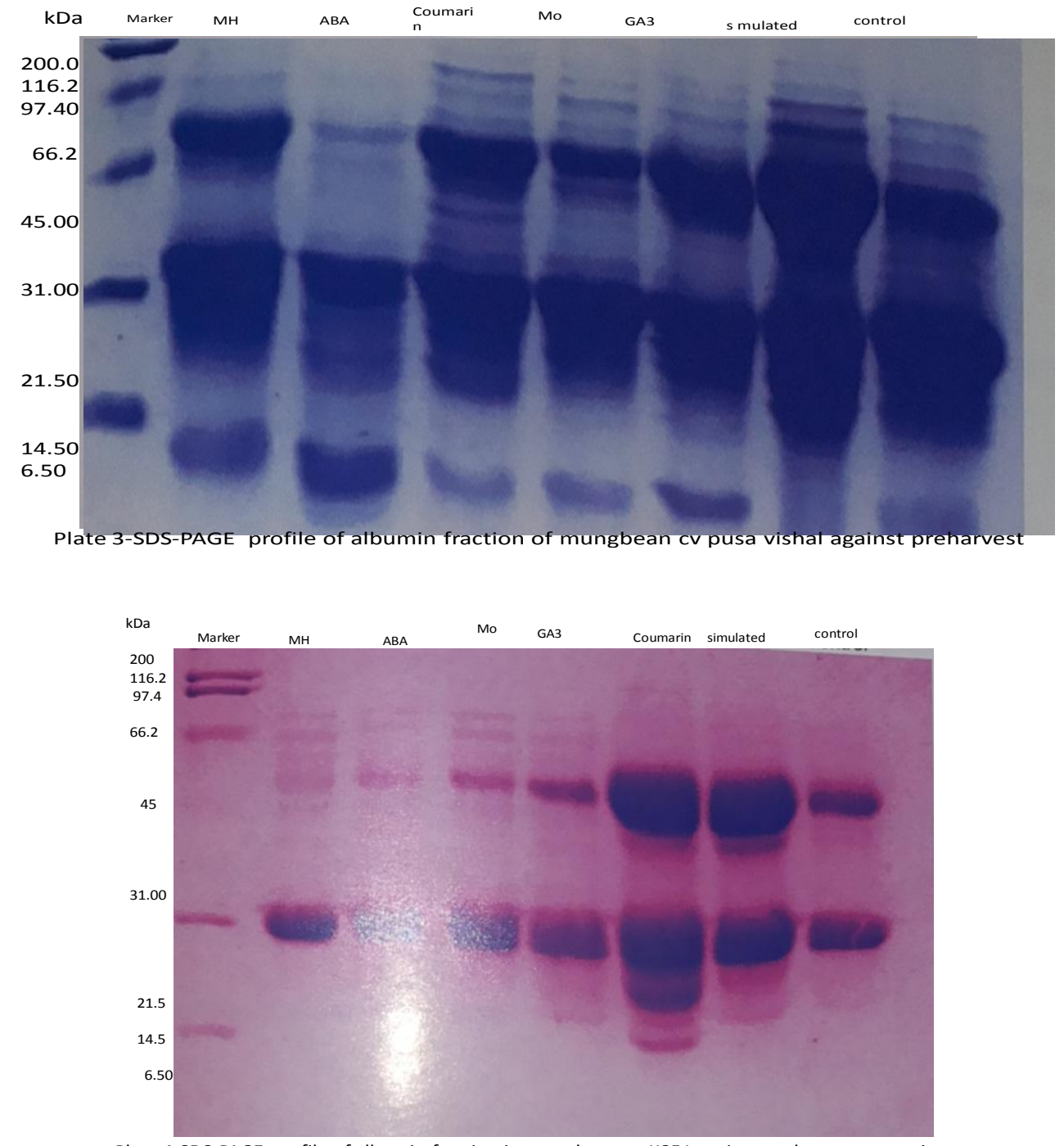

Plate 4-SDS-PAGE profile of albumin fraction in mungbean cv K851 against preharvest sprouting

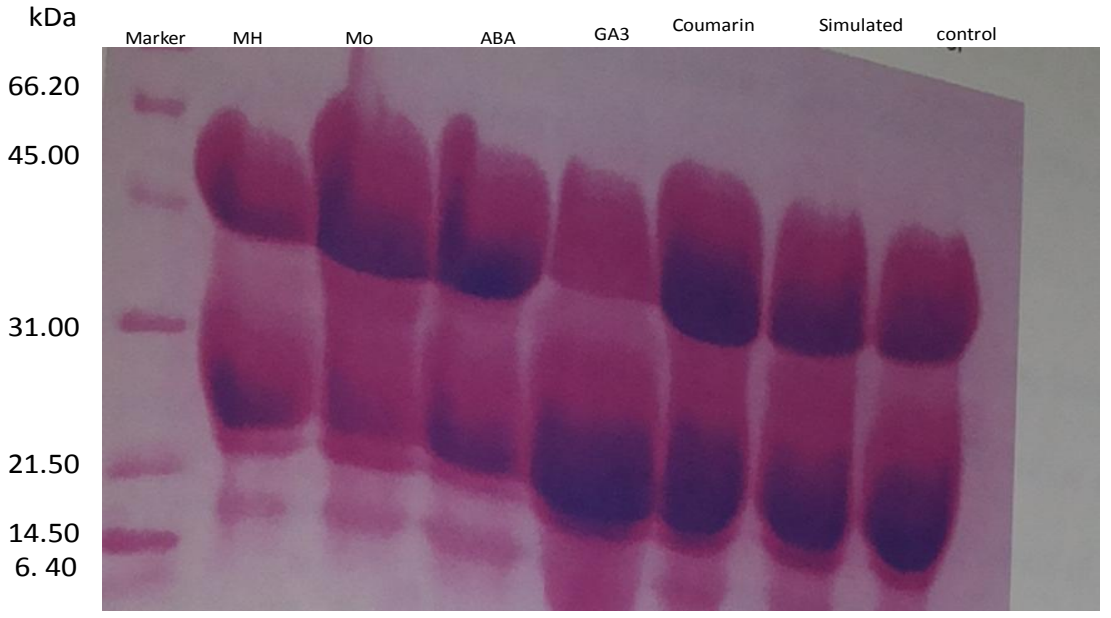

Plate -5 SDS-PAGE profiling of globulin fraction of mungbean cv HUM16 against preharvest sprouting 
Int.J.Curr.Microbiol.App.Sci (2018) 7(5): 539-550

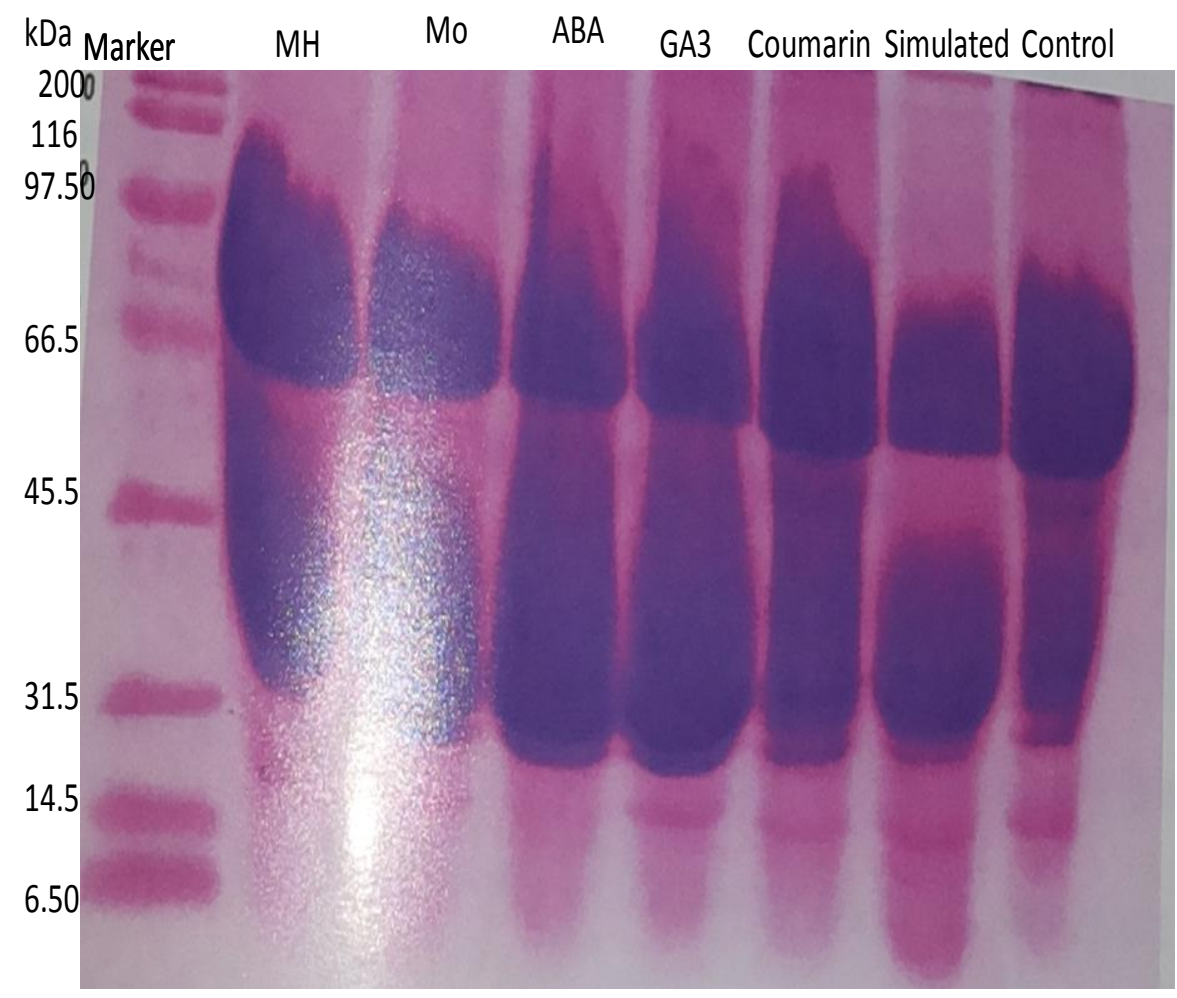

Plate6-SDS-PAGE profiling of globulin fraction of mungbean cv Samrat against preharvestssprouting

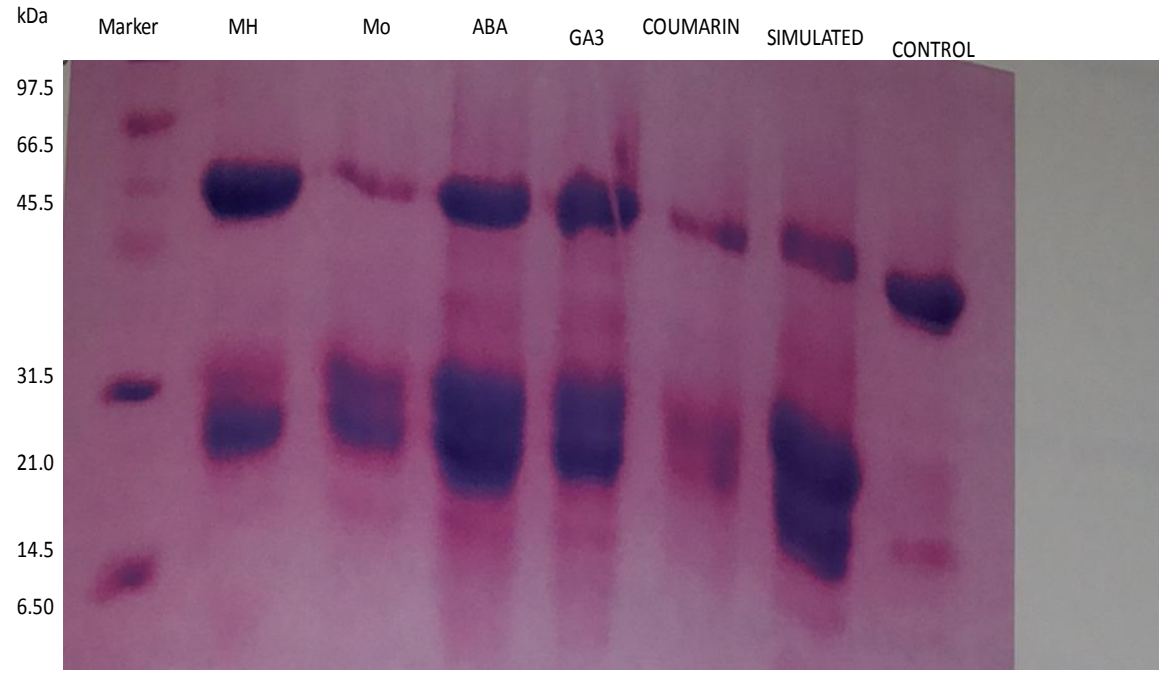

Plate 7-SDS-PAGE profile of globulin fraction of mungbean cv Pusa vishal against pre harvest sprouting 
Plate.8 SDS-PAGE profile of globulin fraction of mungbean cv. K851 against pre-harvest sprouting

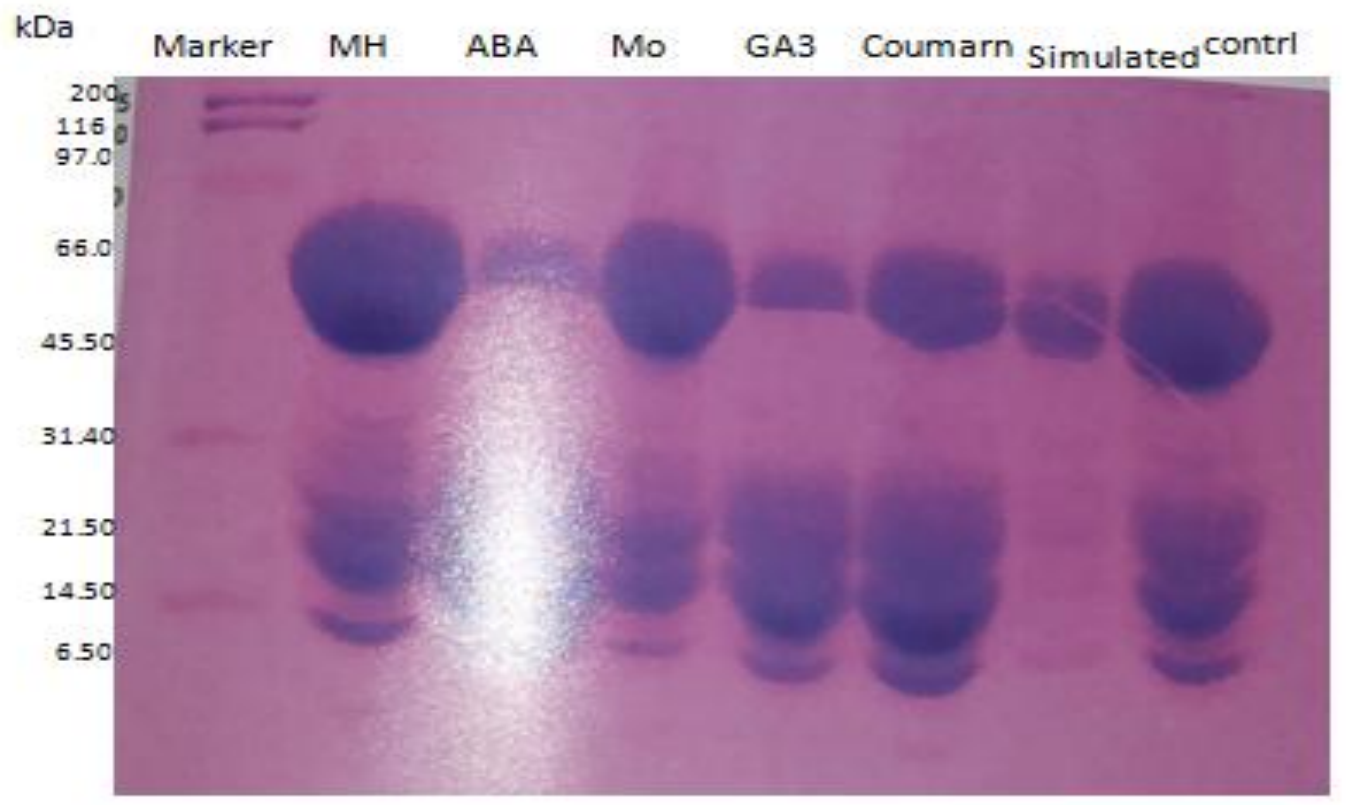

\section{Globulin}

\section{HUM16}

SDS-PAGE analysis of salt extractable seed proteins from mungbean $\mathrm{cv}$. pusa vishal is showed in plate 5. An intensely stained but of low molecular weight of protein bands ranged from $8-56 \mathrm{kDa}$. There were only five bands found common in all treatments except $\mathrm{GA}_{3}$ which recorded 6 . The polypeptides with28 and $35 \mathrm{kDa}$ found commonly in all treatments and were intensely stained. Shown in plate 5

\section{Samrat}

The SDS-PAGE analysis of seed globulin fraction of pre harvest sprouting susceptible mungbean cv. samrat was furnished in plate 6 . The banding pattern showed a wide range from 5-55 $\mathrm{kDa}$ comprising bands ranging from of low molecular weight and high intense bands. No conspicuous differences could be observed in the banding pattern of these proteins. Two extra bands of $5 \mathrm{kDa}$ and $6 \mathrm{kDa}$ were observed de novo in simulation. The polypeptide with $36 \mathrm{kDa}$ was commonly found in untreated control, simulation, ABA, $\mathrm{MH}$, and coumarin treatments while it was absent in $\mathrm{GA}_{3}$ treated seeds.

\section{Pusa vishal}

SDS-PAGE analysis of globulin extracts of seed samples of mungbean genotype pusa vishal effected by different treatments under simulation as shown in plate 7.The electrophoretic studies revealed that the synthesis of protein of high and low molecular weight with high intensity were observed in all treatments. The banding pattern ranged from 140-139kDa. Protein bands with heavy molecular weight 139 and $140 \mathrm{kDa}$ were observed only in ABA treatment, while that $22 \mathrm{kDa}$ was found in all the treatments. Among all treatments 
coumarin exhibited two bands while $\mathrm{GA}_{3}$ and $\mathrm{Kno}_{3}$ could produce a maximum of six bands. Extra protein bands 39, $35 \mathrm{kDa}$ were observed de novo only in $\mathrm{GA}_{3}$ and $\mathrm{Kno}_{3} 30 \mathrm{kDa}$ in simulated rain. The protein bands of 48, 2 and $18 \mathrm{kDa}$ of control were also found commonly in all treatments. De novo development of only two bands of 57 and $22 \mathrm{kDa}$ in coumarin treatmenet indicated further synthesis of proteins.

\section{K851}

The SDS PAGE analysis banding pattern of salt extractable globulin of mung bean genotype K851 is showed in plate 8. The electrophoretic analysis is general showed a ranged $6-154 \mathrm{kDa}$ protein bands were resolved. In respect of K851 the protein bands of 20 and $16 \mathrm{kDa}$ were found intense and common in all treatments. The variation in banding pattern due to different treatments revealed occurrence of both qualitative and quantitative differences. A maximum number of eleven bands developed in coumarin treatment while minimum number of six bands was found in control. The protein band of high molecular weight, $154 \mathrm{kDa}$ was specifically found with coumarin treatment. While a protein band of low molecular weight, $28 \mathrm{kDa}$ was specific to $\mathrm{GA}_{3}$.

\section{Effect of chemical regulation of pre harvest sprouting on quality of seed proteins}

The pods and seeds are subjected to wetting /simulated rain as mentioned earlier, since the seeds wetting leads to sprouting carbohydrates, fats or protein in order would be subjected to degradative processes by their respective enzyme leading to simple molecules. These simple molecules latter would be utilized in enhancing respiration. Since chemical regulation affects sprouting ability or its process in seeds, there may be a varied significantly and maximum content was noticed in pusa vishal. Coumarin treatment resulted in high albumin fraction over untreated control and simulated rain. Coumarin enhanced the albumin content in pre harvest sprouting susceptible and tolerant (K851) genotypes. albumin content was increased in pusa vishal followed by $\mathrm{k} 851$ and HUM16 followed by samarat 34,26 and 22\% respectively by coumarin@100ppm MH@80ppm, ABA @100ppm and GA 3 had least effect on albumin. However the SDSPAGE of seed albumin in pusa vishal showed 9-13bands to $110-5.28 \mathrm{kDa}$ induced by coumarin. Coumarin exclusively induces a new profile of albumin protein of $15.96 \mathrm{kDa}$. it may have some inhibitory effect on sprouting in coumarin treated mungbean seeds, where as a low intensive bands of molecular weight $42 \mathrm{kDa}$ weight was observed exclusively in control which may be a specific protein induced under simulation causing sprouting. pusa vishal treated mungbean, whereas a low intensive bands of molecular weight -kDa was observed exclusively in control. Which may be a specific protein induce under simulation causing sprouting in HUM16 could show 12 band ranging 9.14-63.6 kDa. Coumarin also induced 11 bands but all the treatments exhibited more number of high molecular weight protein bands ranging 9.14-83.50kDa. Albumin is known soluble proteins. They are hydrophilic and help in water absorption, hence prone seeds for sprouting when wet. The coumarin treatment could develop about 12 bands ranging from $20-110 \mathrm{kDa}$. It shows that coumarin treatment could influence the protein banding pattern. Pusa vishal showed heavy bands ranging $6.4-134 \mathrm{kDa}$. The polypeptide of high intensity corresponding 33 and 26kDa under simulated condition. This may be responsible for low sprouting under simulation. While a similar polypeptide band profile of $31-26 \mathrm{kDa}$ induce by $\mathrm{k} 851$ as under all the treatments a heavy $111.2 \mathrm{kDa}$ was also found specifically under coumarin treatment which might have imparted the trait of 
tolerance to pre harvest sprouting under simulated rain. Further it developed a $33 \mathrm{kDa}$ protein only under simulation but not in other treatments. This might be responsible for nonsprouting under simulation.

Other hand, globulin are salt soluble protein hydroponic in nature and their presence in seeds which may partially resist water absorption. The presence of higher globulin content $(30.19 \mathrm{mg})$ in pusa vishal is contributing to the tolerance to pre harvest sprouting under simulation. The HUM16 a $31 \mathrm{kDa}$ band synthesized de novo, only with $\mathrm{MH}$ signify that it might imparts tolerance to pre harvest sprouting. The may be different protein from other that might be serve as molecular marker for sprouting tolerance. Samrat showed de novo synthesis of 5 and 6 band $\mathrm{kDa}$ under wetting/simulated rainfall condition. Pusa vishal showed heavy bands of 139and $140 \mathrm{kDa}$ particularly in $\mathrm{MH}$ which may be responsible for non-sprouting of pusa vishal under $\mathrm{MH}$ treatment may serve a molecular marker protein for imparting tolerance to pre harvest sprouting. Coumarin were also exhibited only 2bands of 57 and 22 $\mathrm{kDa}$ de novo, while ABA produced 6bands each. However, the specificity of de novo produced protein need confirmatory studies.

K851 specifically developed a high molecular weight $(154 \mathrm{kDa})$ protein under coumarin treatment and a low molecular weight of $28 \mathrm{kDa}$ under $\mathrm{GA}_{3}$. Accordingly the $154 \mathrm{kDa}$ protein may be used as marker against pre harvest sprouting tolerance by $\mathrm{MH}$.

The order of high globulin content in K851, Pusa vishal, HUM16, Samrat also confirm their tolerance to sprouting in the same decreasing order. Thus the study of chemical regulation of pre harvest sprouting in the present investigation suggest that specific protein markers synthesized de novo could impart tolerance to PHS is quantitative inherited and strongly affected by environmental factors.

Based on the pre harvest sprouting damage caused by weather and percent reduction in seed yield, the genotype viz. pusa vishal, K851 could be considered as a pre harvest sprouting tolerant genotype while HUM16 and Samrat as a pre harvest sprouting susceptible. The susceptibility was characterized by the presence of high water soluble albumin fraction and relatively low globulin content in HUM16 and Samrat. Prevention of pre harvest sprouting in susceptible genotype was very effective with foliar spray of coumarin and $\mathrm{MH}$ followed by ABA.

\section{References}

Appalanaida, B. and Murthy, K. S. (1961). Effect of maleic hydrazide on ragi. The Andhra Agric. J., 8: 168-175.

Ashok Kumar, T. S. (1989). M.Sc. (Agri.) thesis, Univ. Agric. Sci., Dharwad.

Berrie, A. M. Parker, W. Knight, B. A. and Hendrie, M. R. (1968). Studies on lettuce seed germination coumarin induced dormancy. Photochemistry 7: 567-573.

Berry, T. A. and Bewley, J.D. (1992). A role for the surrounding fruit tissues in preventing germination of tomato (Lycopersicon esculentum) seeds. A consideration of the osmotic environment and abscisic acid. Plant Physiology 100: 951-957.

Bhuyan, J. and Sharma, M.K (2006). A preliminary study on pre harvest sprouting in soyabean (Glycine max (L)). 4(1/6); 77-79.4ref.

Bott, W. and Kingston, R. W. (1976). Mungbeans: an important new grain legume Queensland Agriculture Journal 102: 438-442. 
Calero, E. West, S.H. and Hinson, K. (1981). Water absorption of soyabean seeds and associated causal factors. Crop Sci 21: 926-933.

Chen, Guang. Yao. Wang, Guo. Huai. Luo, Feng. Nie. Ming, Jian (2007). Effect of endogenous hormone on pre harvest sprouting in siliqua of rapseed (Brassica napus L.). Journal of Acta Agronomica Sinica 33(8): 1324-1328.15ref.

Davidson, S. (1985) Developing mungbeans resistant to weathering. Rural Research 28:31.

Derera, N. F. (1989). The effects of pre harvest rain. Pre harvest field sprouting in cereals. Pp. 1-14.

Dickson, M. H (1980). Genetics aspects of seed quality. Horticulture Science 15: 771-774.

Durga, K.K. and Kumar, S.S. (1997). Screening for Pre-harvest Sprouting in Pulses. Legume Research. 20, 193-197.

Fisher, R.A. and Yates, F. (1963).Statistical tables for Biological Agri. and Medical Res. Olver and Bryd Endinburg VIEd.

Gubler, F. Millar, A. A. and Jacobsen, J. V (2005). Dormancy released, ABA and pre harvest sprouting. Current Opinion in Plant Biology, 8(2): 183-187.

Hilhorst, H. W. M. (1995). A critical update on seed dormancy I. Primary Dormancy Seed Science Research, 5:61-73.
Imrie, B. C. (1983). Response to selection for weathering resistance in mungbean. Proceeding of Australian Plant Bredders Conference Adelaide. Pp 348-350.

Karssen, C. M. Brinkhorst - Van der Swan, D. L. C. Breekland, A. E. and Koornnef, M. (1983). Induction of dormancy during seed development by endogenous abscisic acid: Studies On abscisic acid deficient genotypes of Arabidopsis thaliana (L) Heynh. Planta, 157:158-165.

Laemmil, U. K. (1970). Cleavage of structural proteins during the assembly of the head of bacterio phage T4. Nature 227:680685.

Lakhanpaul, S.S.C. and Bhat, K.V. (2000) Random amplified polymorphic DNA (RAPD) analysis in Indian mungbean (Vigna radiata (L.) Wilczek) cultivars. Genetica., 109, 227-234.

Lepage Degivry, M. T. and Garello, G. (1992). In situ abscisic acid synthesis. A requirement for induction of embryo dormancy in Helianthus annus. Plant Physiology, 98:13861390.

Naik and Kole (2001). Electrophoretic studies on seed protein profile of mungbean. Legume Research, Vol. 24(3): 169-173.

\section{How to cite this article:}

Priyanka Singh, V.K. Chourasiya and Yadav, R.D.S. 2018. Effect of Chemical Treatment on Protein Profiling Against Pre-Harvest Sprouting in Mung Bean. Int.J.Curr.Microbiol.App.Sci. 7(05): 539-550. doi: https://doi.org/10.20546/ijcmas.2018.705.068 